\title{
Prevalence, antimicrobial susceptibility and virulence gene profiles of Arcobacter species isolated from human stool samples, foods of animal origin, ready-to-eat salad mixes and environmental water
}

\author{
Dainius Uljanovas ${ }^{1 *}\left(\mathbb{D}\right.$, Greta Gölz² Vanessa Brückner $^{2}$, Audrone Grineviciene ${ }^{3}$, Egle Tamuleviciene ${ }^{4}$,
}

Thomas Alter $^{2}$ and Mindaugas Malakauskas ${ }^{1}$

\begin{abstract}
Background: Members of the genus Arcobacter are considered as emerging zoonotic food and waterborne pathogens that cause gastroenteritis and bacteremia in humans. However, the potential risk that Arcobacter species pose to public health remains unassessed in various countries, including Baltic states. Therefore, the aim of this study was to determine the prevalence, antimicrobial susceptibility and presence of putative virulence genes of Arcobacter isolates recovered from humans, food products and environmental water in Lithuania.
\end{abstract}

Results: A total of 1862 samples were collected and examined from 2018 to 2020 in the city of Kaunas. Overall, 11.2\% ( $n=208$ ) of the samples were positive for the presence of Arcobacter spp. The highest prevalence was detected in chicken meat (36\%), followed by environmental water (28.1\%), raw cow milk (25\%), ready-to-eat salad mixes (7.1\%) and human stool (1.7\%). A. butzleri was the most frequently isolated species ( $n=192 ; 92.3 \%)$, followed by A. cryaerophilus ( $n=16 ; 7.7 \%$ ). Arcobacter spp. antimicrobial susceptibility testing revealed unimodally distributed aggregated minimal inhibitory concentrations (MICs) for gentamicin, tetracycline, ciprofloxacin, ampicillin and erythromycin. However, a bimodal distribution for azithromycin was found with $96.2 \%$ of determined MICs above the epidemiological cut-off value (ECOFF) defined for Campylobacter jejuni $(0.25 \mu \mathrm{g} / \mathrm{ml})$. Majority of the Arcobacter isolates $(\mathrm{n}=$ 187; 89.9\%) showed high susceptibility to ciprofloxacin with MICs below or equal to the ECOFF value of $0.5 \mu \mathrm{g} / \mathrm{ml}$. The putative virulence genes cadF (100\%), ciaB (100\%), cj1349 (99\%), tlyA (99\%), mviN (97.9\%) and pldA (95.8\%) were the predominant genes detected among A. butzleri isolates. In contrast, the mviN and ciaB genes were present in all, whereas cj1349 (12.5\%), tlyA (25\%) and hecA (12.5\%) were only detected in few A. cryaerophilus isolates.

Conclusions: Our results demonstrate that food products and environmental water in Lithuania are frequently contaminated with Arcobacter spp. that carry multiple putative virulence genes. Furthermore, A. butzleri were isolated from $1.7 \%$ of inpatients. Fluoroquinolones and aminoglycosides were found to be more effective against Arcobacter in

\footnotetext{
*Correspondence: dainius.uljanovas@Ismuni.It

${ }^{1}$ Department of Food Safety and Quality, Faculty of Veterinary Medicine,

Veterinary Academy, Lithuanian University of Health Sciences, Kaunas, Lithuania

Full list of author information is available at the end of the article
}

(c) The Author(s) 2021. Open Access This article is licensed under a Creative Commons Attribution 4.0 International License, which permits use, sharing, adaptation, distribution and reproduction in any medium or format, as long as you give appropriate credit to the original author(s) and the source, provide a link to the Creative Commons licence, and indicate if changes were made. The images or other third party material in this article are included in the article's Creative Commons licence, unless indicated otherwise in a credit line to the material. If material is not included in the article's Creative Commons licence and your intended use is not permitted by statutory regulation or exceeds the permitted use, you will need to obtain permission directly from the copyright holder. To view a copy of this licence, visit http://creativecommons.org/licenses/by/4.0/. The Creative Commons Public Domain Dedication waiver (http://creativecommons.org/publicdomain/zero/1.0/) applies to the data made available in this article, unless otherwise stated in a credit line to the data. 
comparison to other antimicrobial agents. However, further studies are needed to determine the pathogenic mechanisms and factors that facilitate the spread of Arcobacter infections.

Keywords: Arcobacter, Humans, Food, Environmental water, Prevalence, Antimicrobial susceptibility, Virulence genes

\section{Background}

The genus Arcobacter was proposed in 1991 [1] based on DNA-rRNA, DNA-DNA hybridization and immunotyping analysis of Campylobacter and related organisms. Since then, a total of 29 species for this genus have been described [2]. Recently, Pérez-Cataluña et al. [3] proposed to divide the genus into seven different genera, however, the newly proposed classification is still under debate $[4,5]$. Due to their ability to form biofilms on abiotic surfaces and survive in different conditions, Arcobacter species are widely distributed throughout the food chain and environment [6,7]. Arcobacter spp. have been isolated from various sources: farm environment, animals, vegetables and food products of animal origin (at the processing stage and retail), food-processing facilities, environmental waters, sewage and floodwater [8-11]. Consumption of contaminated food of animal origin (meat, milk, seafood), vegetables or water is considered as the main route of transmission to humans [6]. Clinical symptoms associated with Arcobacter gastrointestinal infections in humans include persistent aqueous diarrhea, abdominal pain and fever [7, 8]. However, infections of immunocompromised patients can result in bacteremia, peritonitis and endocarditis $[6,12,13]$. The majority of Arcobacter infections among humans and animals are caused by Arcobacter (A.) butzleri, A. cryaerophilus and, to a lesser extent, $A$. skirrowii and $A$. thereius [14-16]. Given that there are no routine diagnostic procedures designed for the detection of Arcobacter spp., their prevalence and significance of infections might be underestimated. To date, the reported prevalence of Arcobacter among humans range from 0.3 to 4\% $[17,18]$. Recent studies have shown that Arcobacter was the second and fourth most common bacterial pathogen isolated from human stool samples in Germany and Belgium, respectively $[14,19]$.

Similar to Campylobacter, Arcobacter cause self-limiting infections which do not require antimicrobial therapy, although cases of severe and chronic enteritis may necessitate the use of antibiotics [8]. Fluoroquinolones, tetracyclines, macrolides, aminoglycosides and a combination of $\beta$-lactam antibiotics with $\beta$-lactamase inhibitors are suggested as viable treatment options in these cases $[11,20]$. Nonetheless, a recent meta-analysis indicated that between 69.3 and $99.2 \%, 4.3-14 \%, 10.7-39.8 \%$ and $0.8-7.1 \%$ of Arcobacter spp. isolates have shown reduced susceptibility to penicillins, fluoroquinolones, macrolides and tetracyclines, respectively [21]. Furthermore, other studies revealed reduced susceptibility to multiple antimicrobials in up to $89 \%$ of Arcobacter strains isolated from human clinical samples, food products and environment [22-24].

In vitro human and animal cell culture assays have shown that Arcobacter spp. have pathogenic properties (adhesion, invasion, cytotoxicity and ability to upregulate interleukin-8 expression) that are significant for the colonization of host tissues and establishing infection [25, 26]. Several studies investigated adhesive, invasive and/ or cytotoxic capabilities of $A$. butzleri strains isolated from various sources (reviewed by Chieffi et al.) [7]. In summary, $25-100 \%$ of tested strains were able to induce cytotoxic effects, $12.5-100 \%$ to adhere and $0-100 \%$ to invade different cell lines (Caco-2, Hep-2, Vero, HT-29, HeLa). Bücker et al. [27] observed that infection of human colonic cells (HT-29/B6) with A. butzleri results in a decreased expression of integral transmembrane proteins (claudin-1, -5, -8) and induction of epithelial apoptosis, which are mechanisms that are consistent with a leak flux type of diarrhea. The analysis of A. butzleri RM4018 whole genome sequence revealed the presence of ten putative virulence-associated genes ( $c a d F, c j 1349$, ciaB, mviN, pldA, tlyA, irgA, hecA, hecB, iroE) that have homologs in other pathogens (e.g. C. jejuni, V. cholerae and uropathogenic E. coli) [28].

To date, no studies were carried out to determine the Arcobacter prevalence among humans in Lithuania or other Baltic states. The absence of data on contamination of food products and environment, antimicrobial resistance, and occurrence of putative virulence genes complicates the assessment of the potential risk to public health. Therefore, the objectives of this study were (i) to determine the prevalence of Arcobacter spp. in different sources (human stool samples, foods of animal origin, ready-to-eat salad mixes and environmental water), (ii) to assess the antimicrobial susceptibility patterns of isolated bacteria and to obtain minimal inhibitory concentration (MIC) distribution data, and (iii) to evaluate the pathogenic potential of strains by determining the occurrence of virulence-associated genes.

\section{Results}

\section{Prevalence of Arcobacter}

As summarized in Table 1, Arcobacter spp. were isolated from $208(11.2 \%)$ out of the 1862 samples tested. The 
Table 1 Prevalence of Arcobacter spp. in the examined samples

\begin{tabular}{|c|c|c|c|c|c|c|}
\hline \multirow[t]{2}{*}{ Matrix } & \multirow[t]{2}{*}{ Sampling period ${ }^{a}$} & \multirow[t]{2}{*}{ No. of samples } & \multicolumn{4}{|c|}{ No. of positive samples (\%) } \\
\hline & & & Arcobacter spp. & A. butzleri & A. cryaerophilus & A. skirrowii \\
\hline Chicken meat & $10.2018-09.2019$ & 331 & $119(36)^{a}$ & $114(95.8)$ & $5(4.2)$ & - \\
\hline Raw cow milk & $01.2019-12.2019$ & 104 & $26(25)^{\mathrm{b}}$ & $26(100)$ & - & - \\
\hline RTE salad mixes & $\begin{array}{l}11.2018-03.2019 \text { and } \\
05.2019-10.2019\end{array}$ & 99 & $7(7.1)^{c}$ & $2(28.6)$ & $5(71.4)$ & - \\
\hline Environmental water & $12.2018-11.2019$ & 128 & $36(28.1)^{a, b}$ & $30(83.3)$ & $6(16.7)$ & - \\
\hline Human stool & $03.2019-02.2020$ & 1200 & $20(1.7)^{d}$ & $20(100)$ & - & - \\
\hline Total & & 1862 & $208(11.2)$ & $192(92.3)^{\mathrm{e}}$ & $16(7.7)^{f}$ & - \\
\hline
\end{tabular}

${ }^{a-d}$ Values in the same column denoted by different superscript letters are significantly different $(P<0.05)$

e,f Values in the same row denoted by different superscript letters are significantly different $(P<0.05)$

isolation rate of Arcobacter varied among different sample types; the highest prevalence was in chicken meat (36\%), followed by environmental water (28.1\%), raw cow milk (25\%), ready-to-eat (RTE) salad mixes (7.1\%) and human stool (1.7\%). Only two species were identified by multiplex PCR and rpoB sequencing: $A$. butzleri (192 of 208 isolates, 92.3\%) and A. cryaerophilus (16 of 208 isolates, 7.7\%). A. butzleri was recovered from all sources, whereas $A$. cryaerophilus was only isolated from RTE salads (5 of 99 samples, 5.1\%), surface waters (6 of 128 samples, 4.7\%) and chicken meat (5 of 331 samples, $1.5 \%)$. A. butzleri was the predominant species in most sources except RTE salad mixes, where A. cryaerophilus was more prevalent.

\section{Antimicrobial susceptibility}

The results of antimicrobial susceptibility testing (AST) of 208 Arcobacter spp. isolates revealed unimodally distributed aggregated minimal inhibitory concentrations (MICs) for gentamicin, tetracycline, ciprofloxacin, ampicillin and erythromycin, whereas a bimodal distribution for azithromycin was detected (Fig. 1). The MICs of gentamicin and tetracycline were distributed around the epidemiological cut-off (ECOFF) values defined for C. jejuni ( $1 \mu \mathrm{g} / \mathrm{ml}$ for both antimicrobials), with no interspecies differences (Fig. 1; Table 2). In case of gentamicin, MIC values ranged from 0.125 to $4 \mu \mathrm{g} / \mathrm{ml}$ (mode $=1 \mu \mathrm{g} / \mathrm{ml}$ ), while for tetracycline MICs ranging from 0.125 to $8 \mu \mathrm{g} /$ $\mathrm{ml}($ mode $=2 \mu \mathrm{g} / \mathrm{ml}$ ) were observed (Table 2). The range of MICs for macrolides was wider in comparison to other tested antimicrobial agents. For erythromycin, MIC values were distributed around the ECOFF for $C$. jejuni and peaked at $4 \mu \mathrm{g} / \mathrm{ml}$ (Fig. 1). However, $96.2 \%$ of determined MICs (ranging from 0.5 to $>256 \mu \mathrm{g} / \mathrm{ml}$; Table 2) for azithromycin were above the ECOFF of $C$. jejuni $(0.25 \mu \mathrm{g} /$ $\mathrm{ml}$ ) with peaks at $2 \mu \mathrm{g} / \mathrm{ml}$ and $16 \mu \mathrm{g} / \mathrm{ml}$ (Fig. 1). Additionally, 67.7\% (130/192) of $A$. butzleri and $12.5 \%(2 / 16)$ of $A$. cryaerophilus isolates formed a subpopulation (MICs $\geq$
$8 \mu \mathrm{g} / \mathrm{ml}$; Fig. 1), which displayed reduced susceptibility to azithromycin. Most isolates (190/208, 91.3\%) were highly susceptible to ciprofloxacin with MICs distributed on the lower end of the tested concentration range (from 0.032 to $1 \mu \mathrm{g} / \mathrm{ml}$, mode $=0.125 \mu \mathrm{g} / \mathrm{ml}$; Table 2). However, $8.9 \%$ (17/192) of $A$. butzleri and 6.3\% (1/16) of A. cryaerophilus strains showed elevated MICs for ciprofloxacin $(\geq$ $8 \mu \mathrm{g} / \mathrm{ml}$; Table 2). The MICs of ampicillin (ranging from 0.5 to $>256 \mu \mathrm{g} / \mathrm{ml}$, mode $=16 \mu \mathrm{g} / \mathrm{ml}$; Table 2) were distributed around the ECOFF for C. jejuni $(8 \mu \mathrm{g} / \mathrm{ml}$; Fig. 1$)$. The majority of $A$. cryaerophilus isolates (13/16, 81.3\%) displayed MIC values that were below or equal to the ECOFF, while MICs of $72.9 \%$ (170/192) A. butzleri isolates were above and 2-32 times higher (Table 2).

\section{Occurrence of putative virulence genes}

The detection of ten putative virulence genes by PCR in $192 \mathrm{~A}$. butzleri and $16 \mathrm{~A}$. cryaerophilus isolates from food, environmental water and human clinical samples is summarized in Table 3. Regardless of species, the ciaB gene was present in all Arcobacter isolates. Similarly, $98.1 \%$ of tested strains harbored the mviN gene, while other genes were less frequently detected. Overall, all putative virulence-associated genes were detected among the analyzed $A$. butzleri isolates, whereas only five were identified in $A$. cryaerophilus. The majority of $A$. butzleri isolates carried cadF (100\%), ciaB (100\%), cj1349 (99\%), tlyA (99\%), mviN (97.9\%) and pldA (95.8\%) genes. However, lower detection rates were observed for hecB (38.5\%), hecA (20.3\%), iroE (18.8\%) and $\operatorname{irgA}(12.5 \%)$. In contrast, for $A$. cryaerophilus only the $m v i N$ and ciaB genes were detected in all isolates, and $t l y A$ was found only in four (25\%) isolates. Furthermore, the cj1349 and hecA genes were detected in two (12.5\%) A. cryaerophilus isolates.

Overall, 7.3\% (14/192) of A. butzleri isolates (seven from chicken meat and seven from environmental water) harbored all ten putative virulence genes (Table 4). 

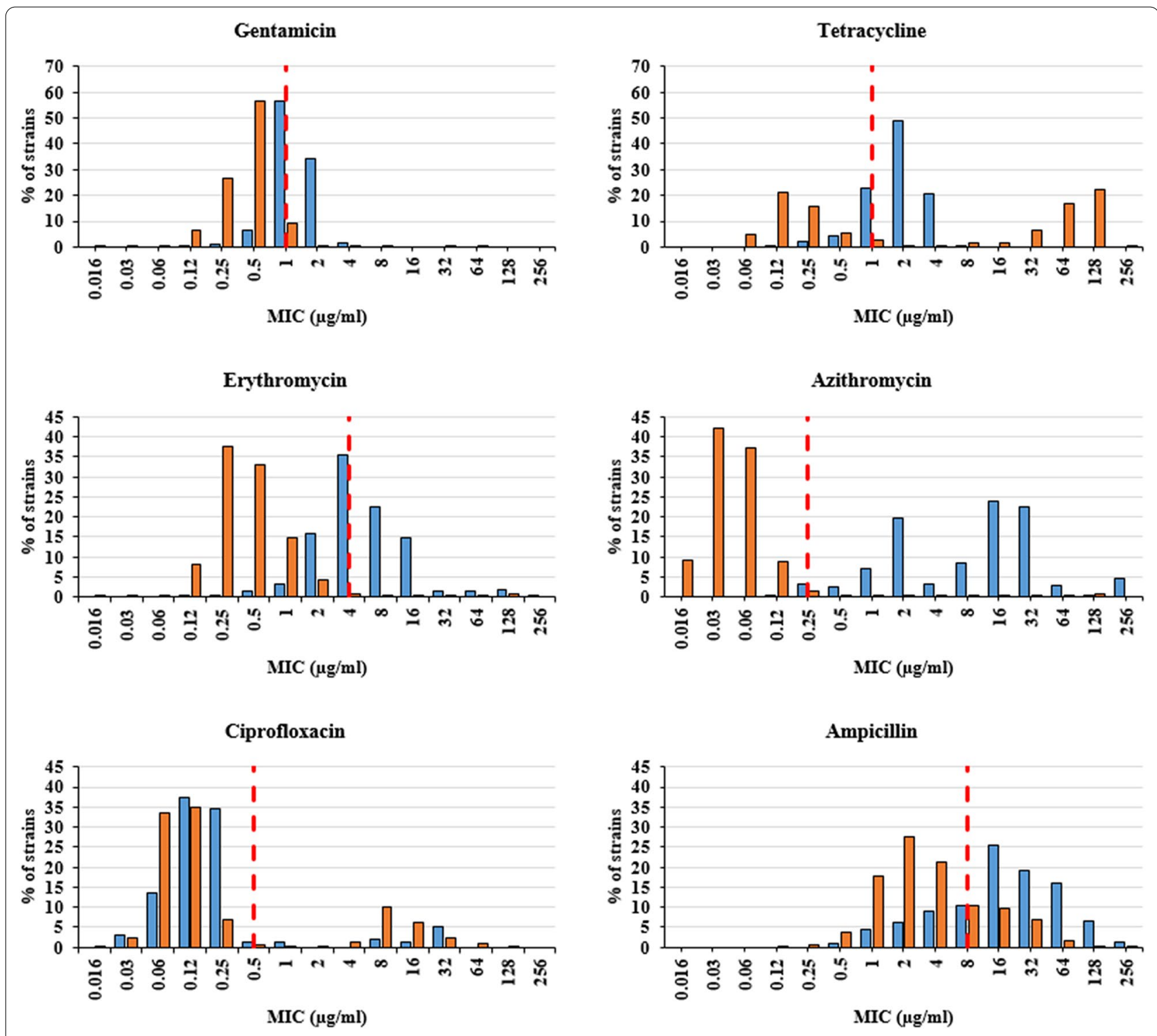

Fig. 1 Aggregated MIC distributions of Arcobacter spp. isolated from food, environmental water and human stool samples. In addition to the MICs of the Arcobacter spp. strains (blue) isolated in our study, the epidemiological cut-off values (ECOFFs) (red broken lines) and MICs of C. jejuni (orange) from the EUCAST database are also shown [29]. E-test half-log values were rounded up to the next highest value of the standard doubling dilution scale. In order to prevent numerical dominance of EUCAST MIC distributions, number of isolates at each MIC value are presented as percentage of the total observations from individual dataset

Meanwhile, for $A$. cryaerophilus, a maximum of four genes was detected in two isolates (one from meat and one from water) by our PCR; however, the majority of isolates $(10 / 16,62.5 \%)$ simultaneously carried two genes (ciaB and $m v i N)$. Among A. butzleri isolates, the most common $(96 / 192,50 \%)$ virulence gene pattern was ciaB, mviN, pldA, tlyA, cj1349 and cadF. This profile was observed in isolates from chicken meat, raw cow milk, environmental water and human stool samples with rates of $60.5 \%, 50 \%, 23.3 \%$, and $35 \%$, respectively. Only $35.2 \%$ of $A$. butzleri strains from food samples carried at least seven putative virulence genes, while higher rates were determined for strains from human stool samples (60\%) and environmental water (76.7\%).

Statistical analysis revealed no significant differences between the occurrence of ciaB, mviN, pldA, tlyA, cj1349, $c a d F$ genes in A. butzleri isolates of different origin (food, environmental water and human stool samples, $\mathrm{P}>0.05$ ). 
Table 2 MIC data on six antimicrobial agents for 192 A. butzleri and 16 A. cryaerophilus isolates

\begin{tabular}{|c|c|c|c|c|c|c|c|c|c|c|c|c|c|c|c|c|c|c|}
\hline \multirow[t]{2}{*}{ ATM $^{a}$} & \multirow[t]{2}{*}{ Species } & \multirow[t]{2}{*}{ Source } & \multicolumn{16}{|c|}{ No. of isolates with MIC $(\mu \mathrm{g} / \mathrm{ml})$ of: } \\
\hline & & & 0.03 & 0.06 & 0.13 & 0.25 & 0.5 & 1 & 2 & 4 & 8 & 16 & 32 & $>32$ & 64 & 128 & 256 & $>256$ \\
\hline \multirow[t]{8}{*}{ AM } & A. butzleri & Chicken meat & & & & & 2 & 8 & 8 & 11 & 11 & 27 & 26 & & 15 & 6 & & \\
\hline & A. cryaerophilus & & & & & & & & & 2 & 3 & & & & & & & \\
\hline & A. butzleri & Environmental water & & & & & & 1 & 1 & 1 & & 4 & 5 & & 8 & 7 & 1 & 2 \\
\hline & A. cryaerophilus & & & & & & & & 1 & 2 & 2 & 1 & & & & & & \\
\hline & A. butzleri & RTE salad mixes & & & & & & & & & & & & & 2 & & & \\
\hline & A. cryaerophilus & & & & & & & & 1 & & 2 & 1 & 1 & & & & & \\
\hline & A. butzleri & Raw cow milk & & & & & & & 1 & 1 & & 11 & 6 & & 7 & & & \\
\hline & & Human stool & & & & & & & 1 & 2 & 4 & 9 & 2 & & 1 & 1 & & \\
\hline \multirow[t]{8}{*}{$A Z$} & A. butzleri & Chicken meat & & & 1 & 4 & 1 & 6 & 18 & 5 & 11 & 30 & 26 & & 2 & & 6 & 4 \\
\hline & A. cryaerophilus & & & & & & 1 & 2 & 1 & 1 & & & & & & & & \\
\hline & A. butzleri & Environmental water & & & & & & 1 & 1 & & 4 & 11 & 10 & & 3 & & & \\
\hline & A. cryaerophilus & & & & & 1 & 1 & 2 & 1 & & 1 & & & & & & & \\
\hline & A. butzleri & RTE salad mixes & & & & & & & & & & & 2 & & & & & \\
\hline & A. cryaerophilus & & & & & 2 & 2 & & & & & 1 & & & & & & \\
\hline & A. butzleri & Raw cow milk & & & & & & 3 & 12 & 1 & 1 & 2 & 6 & & 1 & & & \\
\hline & & Human stool & & & & & & 1 & 8 & 0 & 1 & 6 & 3 & & & 1 & & \\
\hline \multirow[t]{8}{*}{ GM } & A. butzleri & Chicken meat & & & & & 6 & 67 & 41 & & & & & & & & & \\
\hline & A. cryaerophilus & & & & & 1 & 1 & 1 & 2 & & & & & & & & & \\
\hline & A. butzleri & Environmental water & & & & & 2 & 22 & 6 & & & & & & & & & \\
\hline & A. cryaerophilus & & & & & 1 & 1 & 1 & 2 & 1 & & & & & & & & \\
\hline & A. butzleri & RTE salad mixes & & & & & & 2 & & & & & & & & & & \\
\hline & A. cryaerophilus & & & & 1 & & & & 4 & & & & & & & & & \\
\hline & A. butzleri & Raw cow milk & & & & & & 13 & 11 & 2 & & & & & & & & \\
\hline & & Human stool & & & & & 3 & 12 & 5 & & & & & & & & & \\
\hline \multirow[t]{8}{*}{ TC } & A. butzleri & Chicken meat & & & & 1 & 4 & 31 & 56 & 22 & & & & & & & & \\
\hline & A. cryaerophilus & & & & & 2 & & & 3 & & & & & & & & & \\
\hline & A. butzleri & Environmental water & & & & & 2 & & 14 & 13 & 1 & & & & & & & \\
\hline & A.cryaerophilus & & & & & 1 & 3 & & 2 & & & & & & & & & \\
\hline & A. butzleri & RTE salad mixes & & & & & & & & 2 & & & & & & & & \\
\hline & A. cryaerophilus & & & & 1 & & & 3 & 1 & & & & & & & & & \\
\hline & A. butzleri & Raw cow milk & & & & & & 7 & 17 & 2 & & & & & & & & \\
\hline & & Human stool & & & & & & 7 & 9 & 4 & & & & & & & & \\
\hline \multirow[t]{8}{*}{ EM } & A. butzleri & Chicken meat & & & 1 & 1 & 1 & 2 & 14 & 43 & 30 & 12 & 3 & & 2 & 4 & & 1 \\
\hline & A. cryaerophilus & & & & & & 1 & 1 & 1 & 2 & & & & & & & & \\
\hline & A. butzleri & Environmental water & & & & & & & 4 & 6 & 11 & 8 & & & 1 & & & \\
\hline & A. cryaerophilus & & & & & & 1 & 1 & 2 & 2 & & & & & & & & \\
\hline & A. butzleri & RTE salad mixes & & & & & & & & & 1 & 1 & & & & & & \\
\hline & A. cryaerophilus & & & & & & & 2 & 2 & & & 1 & & & & & & \\
\hline & A. butzleri & Raw cow milk & & & & & & 1 & 6 & 10 & 3 & 6 & & & & & & \\
\hline & & Human stool & & & & & & & 4 & 11 & 2 & 3 & & & & & & \\
\hline \multirow[t]{8}{*}{$\mathrm{Cl}$} & A. butzleri & Chicken meat & 1 & 8 & 49 & 35 & 3 & 2 & & & 4 & 3 & & 9 & & & & \\
\hline & A. cryaerophilus & & 2 & & & 3 & & & & & & & & & & & & \\
\hline & A. butzleri & Environmental water & & 4 & 11 & 14 & & 1 & & & & & & & & & & \\
\hline & A. cryaerophilus & & & & 1 & 4 & & & & & & & & 1 & & & & \\
\hline & A. butzleri & RTE salad mixes & & & & 2 & & & & & & & & & & & & \\
\hline & A. cryaerophilus & & 1 & & 3 & 1 & & & & & & & & & & & & \\
\hline & A. butzleri & Raw cow milk & 1 & 10 & 7 & 7 & & & & & & & & 1 & & & & \\
\hline & & Human stool & 1 & 6 & 7 & 6 & & & & & & & & & & & & \\
\hline
\end{tabular}

${ }^{\mathrm{a}} \mathrm{ATM}=$ antimicrobials: $\mathrm{AM}=$ ampicillin, $\mathrm{AZ}=$ azithromycin, $\mathrm{GM}=$ gentamicin, $\mathrm{TC}=$ tetracycline, $\mathrm{EM}=$ erythromycin, $\mathrm{Cl}=$ ciprofloxacin 


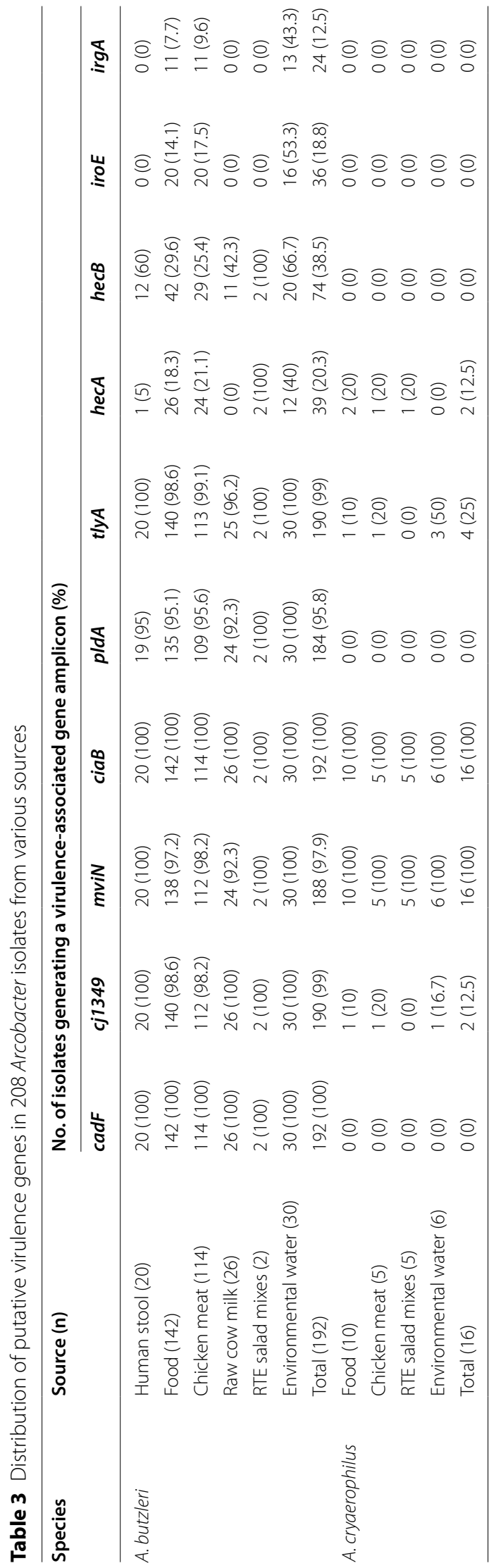


Table 4 Virulence gene profiles of A. butzleri and A. cryaerophilus isolates

\begin{tabular}{|c|c|c|c|c|c|c|c|c|}
\hline \multirow[t]{2}{*}{ Virulence patterns } & \multicolumn{5}{|c|}{ No. of $A$. butzleri isolates (\%) } & \multicolumn{3}{|c|}{ No. of $A$. cryaerophilus isolates (\%) } \\
\hline & $\begin{array}{l}\text { Chicken } \\
\text { meat }(n= \\
114)\end{array}$ & Raw milk $(n=26)$ & $\begin{array}{l}\text { Salad } \\
\text { mixes ( } \mathrm{n} \\
=2 \text { ) }\end{array}$ & Water $(n=30)$ & $\begin{array}{l}\text { Human } \\
\text { stool }(\mathrm{n}= \\
20)\end{array}$ & $\begin{array}{l}\text { Chicken } \\
\text { meat ( } \mathrm{n} \\
=5 \text { ) }\end{array}$ & $\begin{array}{l}\text { Salad } \\
\text { mixes ( } \mathrm{n} \\
=5 \text { ) }\end{array}$ & Water $(n=6)$ \\
\hline \multicolumn{9}{|l|}{2 genes } \\
\hline$c i a B, m v i N$ & & & & & & $3(60)$ & $4(80)$ & $3(50)$ \\
\hline \multicolumn{9}{|l|}{3 genes } \\
\hline ciaB, mviN, tlyA & & & & & & $1(20)$ & & $2(33.3)$ \\
\hline$c i a B, m v i N$, hecA & & & & & & & $1(20)$ & \\
\hline \multicolumn{9}{|l|}{4 genes } \\
\hline ciaB, mviN, hecA, cj1349 & & & & & & $1(20)$ & & \\
\hline ciaB, mviN, tlyA, cj1349 & & & & & & & & $1(16.7)$ \\
\hline \multicolumn{9}{|l|}{5 genes } \\
\hline ciaB, pldA, tlyA, cj1349, cadF & $1(0.9)$ & $1(3.8)$ & & & & & & \\
\hline ciaB, mviN, tlyA, cj1349, cadF & $1(0.9)$ & $1(3.8)$ & & & & & & \\
\hline ciaB, mviN, pldA, tlyA, cadF & $1(0.9)$ & & & & & & & \\
\hline \multicolumn{9}{|l|}{6 genes } \\
\hline $\begin{array}{l}\text { ciaB, mviN, pldA, tlyA, cj1349, } \\
\text { cadF }\end{array}$ & $69(60.5)$ & $13(50)$ & & $7(23.3)$ & $7(35)$ & & & \\
\hline $\begin{array}{l}\text { ciaB, mviN, tlyA, hecB, cj1349, } \\
\text { cadF }\end{array}$ & $1(0.9)$ & $1(3.8)$ & & & $1(5)$ & & & \\
\hline $\begin{array}{l}\text { ciaB, mviN, tlyA, cj1349, iroE, } \\
\text { cadF }\end{array}$ & $1(0.9)$ & & & & & & & \\
\hline $\begin{array}{l}\text { ciab, pldA, tlyA, hecB, cj1349, } \\
\text { cadF }\end{array}$ & & $1(3.8)$ & & & & & & \\
\hline $\begin{array}{l}\text { ciaB, mviN, pldA, hecB, } \\
\text { cj1349, cadF }\end{array}$ & & $1(3.8)$ & & & & & & \\
\hline \multicolumn{9}{|l|}{7 genes } \\
\hline $\begin{array}{l}\text { ciab, mviN, pldA, tlyA, hecA, } \\
\text { cj1349, cadF }\end{array}$ & & & & & $1(5)$ & & & \\
\hline $\begin{array}{l}\text { ciaB, mviN, pldA, tlyA, hecB, } \\
\text { cj1349, cadF }\end{array}$ & $3(2.6)$ & $8(30.8)$ & & $2(6.7)$ & $11(55)$ & & & \\
\hline $\begin{array}{l}\text { ciaB, mviN, pldA, tlyA, cj1349, } \\
\text { iroE, cadF }\end{array}$ & $10(8.8)$ & & & $3(10)$ & & & & \\
\hline $\begin{array}{l}\text { ciaB, mviN, pldA, tlyA, irgA, } \\
\text { cj1349, cadF }\end{array}$ & $1(0.9)$ & & & & & & & \\
\hline $\begin{array}{l}\text { ciaB, mviN, pldA, hecA, hecB, } \\
\text { cj1349, cadF }\end{array}$ & $1(0.9)$ & & & & & & & \\
\hline $\begin{array}{l}\text { ciaB, mviN, pldA, tlyA, hecA, } \\
\text { hecB, cadf }\end{array}$ & $1(0.9)$ & & & & & & & \\
\hline \multicolumn{9}{|l|}{8 genes } \\
\hline $\begin{array}{l}\text { ciaB, mviN, pldA, tlyA, hecA, } \\
\text { hecB, cj1349, cadF }\end{array}$ & $14(12.3)$ & & $2(100)$ & $5(16.7)$ & & & & \\
\hline $\begin{array}{l}\text { ciaB, mviN, pldA, tlyA, irgA, } \\
\text { cj1349, iroE, cadF }\end{array}$ & $1(0.9)$ & & & & & & & \\
\hline \multicolumn{9}{|l|}{9 genes } \\
\hline $\begin{array}{l}\text { ciaB, mviN, pldA, tlyA, irgA, } \\
\text { hecB, cj1349, iroE, cadF }\end{array}$ & $1(0.9)$ & & & $6(20)$ & & & & \\
\hline $\begin{array}{l}\text { ciaB, mviN, tlyA, irgA, hecA, } \\
\text { hecB, cj1349, iroE, cadF }\end{array}$ & $1(0.9)$ & & & & & & & \\
\hline \multicolumn{9}{|l|}{10 genes } \\
\hline $\begin{array}{l}\text { ciaB, mviN, pldA, tlyA, irgA, } \\
\text { hecA, hecB, cj1349, iroE, } \\
\text { cadF }\end{array}$ & $7(6.1)$ & & & $7(23.3)$ & & & & \\
\hline
\end{tabular}


None of the tested $A$. butzleri isolates from human stool specimens carried the $\operatorname{iroE}$ and $\operatorname{irg} A$ genes, while hecA was detected in one isolate (5\%). The highest detection rates of hecA (40\%), $\operatorname{irgA}(43.3 \%)$ and $\operatorname{iroE~(53.3\% )~were~}$ observed among isolates from environmental water. These rates were significantly higher $(P<0.05)$ than the ones determined for isolates from food $(18.3 \%, 7.7 \%$ and $14.1 \%$, respectively). Furthermore, among isolates from human stool and environmental water, the occurrence of $h e c B$ gene $(60 \%$ and $66.7 \%)$ was significantly higher (P $<0.05)$ in comparison with isolates from food samples (29.6\%). The $c a d F$ and $p l d A$ genes were not detected in $A$. cryaerophilus isolates from meat, RTE salad mixes, and water, while these genes were present in majority of $A$. butzleri isolates (rates ranging between 95.6 and 100\%) of same origin.

\section{Discussion}

\section{Arcobacter spp. prevalence in various types of samples}

Research progress on prevalence and pathogenicity has led A. butzleri and A. cryaerophilus to be ranked as serious hazards to human health by the International Commission on Microbiological Specifications for Foods (ICMSF, 2002) [30]. However, due to missing standardized isolation and identification methods, Arcobacter spp. prevalence data in various countries remain undetermined. This appears to be the first study of its kind analyzing the prevalence of Arcobacter spp. in different sources in Lithuania by using Arcobacter-specific detection methods combined with molecular confirmation.

Within the present study, Arcobacter spp. were isolated from 20 out of a total of 1200 (1.7\%) human stool samples tested. There are no epidemiological data provided by other Baltic countries that could be used for comparative analysis. However, this finding is consistent with studies from Belgium and Portugal, where Arcobacter spp. were detected in 1.3\% (89/6774) and 1.7\% (5/298) of clinical stool samples respectively [14, 31]. Other studies, conducted in Turkey, Germany, India, Chile and Belgium, reported different prevalence rates ranging from 0.3 to $4 \%[17-19,32,33]$. After identification using multiplex PCR and verification by rроB sequencing all isolates were classified as A. butzleri. This result is in agreement with previous studies in Turkey and Chile, where A. butzleri was the only species recovered from human feces [17, 32]. According to other authors, A. cryaerophilus and $A$. skirrowii can also be isolated from human stool samples $[14,15,19]$. However, the latter is only rarely detected due to slow growth on culture media and overgrowth by other bacteria, while the prevalence of $A$. cryaerophilus is up to 6.7 -fold lower compared to A butzleri [14, 17, 19, 33]. These are probably the main factors that caused lower species diversity in this study.
Improper hygienic practices at different stages of food supply chain may result in food contamination with Arcobacter spp. Handling and consumption of contaminated food products is considered as one of the main risk factors for human infection [7, 34]. The reported prevalence of Arcobacter spp. in foods varies greatly among different studies. However, most studies agree that the contamination rates of poultry meat are higher in comparison to red meat, raw cow milk and vegetables [23, 35, 36]. As reviewed by Hsu and Lee [9], Arcobacter spp. are more frequently found in food products of animal origin with the highest weighted mean prevalence in chicken meat $(45.2 \%)$, followed by dairy products $(36.4 \%)$, pork (36.3\%), seafood $(32.3 \%)$, beef $(31.2 \%)$ and vegetables (14\%). In this study, Arcobacter spp. were isolated from all tested food products (chicken meat, raw cow milk and RTE salad mixes), with an overall prevalence of $28.5 \%$ (152 of 534 samples). As expected, chicken meat showed the highest contamination levels $(36 \%, 119 / 331)$, followed by raw milk $(25 \%, 26 / 104)$ and RTE salads $(7.1 \%, 7 / 99)$. Part of these results are in agreement with studies from Malaysia and Italy where Arcobacter was detected in 39\% (48/123) of chicken meat and in $21.6 \%(8 / 37)$ of raw cow milk samples [37, 38]. According to other authors, the reported prevalence of Arcobacter spp. in chicken meat and raw cow milk ranged from 12 to $85.7 \%$ and from 4.1 to $46 \%$, respectively $[18,39-41]$. The isolation rate of Arcobacter in RTE salad mixes was lower in comparison with studies conducted in Italy and Portugal (i.e. ranging from 27.5 to $47.6 \%$ ), but higher than the reported contamination of leafy green vegetables $(4.4 \%, 4 / 90)$ from a study in South Korea [23, 42, 43]. Regarding the distribution of species based on sample type, A. butzleri was the only species detected in raw cow milk and the most commonly isolated species in chicken meat (114 out of 119 isolates), whereas in RTE packaged vegetables the most common was $A$. cryaerophilus (5 out of 7 isolates). A. skirrowii was not recovered from tested food samples. These results are in concordance with previous studies that reported A. butzleri as the predominant or the only species (75.4-100\% of isolates) detected in chicken meat and raw cow milk. A. cryaerophilus was the second most commonly isolated species ( $0-21.5 \%$ of isolates), while $A$. skirrowii was rarely found ( $0-3.1 \%$ of isolates) [38-41]. The ability of $A$. butzleri to grow in low temperatures $\left(4-10{ }^{\circ} \mathrm{C}\right)$, attach to various pipe surfaces (i.e. stainless steel, copper and plastic), form biofilms and survive sanitizing procedures explains its persistence in the food processing environment and high isolation rates [44-46]. In case of RTE salads, the higher prevalence of $A$. cryaerophilus was not reported by previous studies. During our survey, pre-washed RTE salad mix samples were tested; therefore, higher $A$. cryaerophilus occurrence in 
vegetables might be associated with a higher capacity to adhere and survive on plant surfaces.

Contaminated water is considered as another important risk factor for public health, and it has been estimated that $63 \%$ of $A$. butzleri infections in humans are related to the consumption of or contact with contaminated water [6]. Arcobacter spp. were isolated from 36 out of 128 (28.1\%) examined environmental water samples. This finding is consistent with a study from Canada, where Arcobacter was detected in 25.6\% (173/676) of surface water samples [47]. However, the prevalence in environmental waters varies greatly across studies, with rates ranging from 20.8 to $58.6 \%[48,49]$. Out of 36 Arcobacter isolates, $A$. butzleri was the most prevalent species $(\mathrm{n}=30)$ followed by $A$. cryaerophilus $(\mathrm{n}=6)$, which is in accordance with other studies $[49,50]$.

Differences between reported Arcobacter prevalence rates in various sources may be due to numerous factors, such as examined sample sizes, geographic and seasonal variation, implemented hygiene protocols and sanitation procedures on farms and food processing facilities, patient populations, sensitivity and specificity of used detection methods. Due to the lack of standard isolation and cultural identification protocols, the latter aspect is of particular importance. According to previous studies, factors like including a pre-enrichment step, media composition and incubation conditions may cause differences in recovery rates ranging from 7.1 to $38 \%$ [43, 51-53]. Furthermore, it should be taken into consideration that only stool samples of inpatients were included in this study. Arcobacter infections are generally mild and do not require hospitalization, hence the overall prevalence might be higher than the one reported here. Nonetheless, Arcobacter was frequently isolated from chicken meat, environmental water, raw cow milk and RTE salads, which is consistent with previous reports.

\section{Antimicrobial susceptibility of isolated bacteria}

At the European Union (EU) level, protocols that were developed by the European Food Safety Authority (EFSA) and the European Centre for Disease Prevention and Control (ECDC) are mainly focused on the harmonized monitoring of antimicrobial resistance in Campylobacter and Salmonella from various sources (i.e. food, foodproducing animals and humans) [54]. In contrast to these zoonotic pathogens, the AST of Arcobacter is not standardized (i.e. there are no reference protocols or defined standard interpretive criteria). Therefore, data on antimicrobial susceptibility of Arcobacter spp. are scarce. Furthermore, the use of different testing methods and breakpoints hinder harmonized monitoring or comparative analysis and can result in therapeutic misguidance. Nevertheless, recent reports have indicated resistance of
Arcobacter spp., isolated from food products, environment and human clinical samples, to several classes of antibiotics (i.e. macrolides, fluoroquinolones, lincosamides, tetracyclines and penicillins) [24, 55-57]. In these studies, resistance was determined by applying European Committee on Antimicrobial Susceptibility Testing (EUCAST) breakpoints for Campylobacter, Enterobacteriaceae and non-species related breakpoints, or Clinical and Laboratory Standards Institute (CLSI) breakpoints for Campylobacter, Enterobacteriaceae and Staphylococcus spp.

In our study, two different methods were used for the isolation of Arcobacter spp. from food products, environmental water and human stool samples. However, strains from different sources showed similar MIC distribution patterns (data not shown). Therefore, MIC data were aggregated and compared with EUCAST ECOFFs for C. jejuni [29]. Although the average nucleotide identity (ANI) between C. jejuni subsp. jejuni NCTC 11,168 and A. butzleri RM4018 is around 67\% [58], Campylobacter is the most closely related genus to Arcobacter for which ECOFFs are available. Regardless of species, none of the tested Arcobacter isolates showed elevated MICs for gentamicin and tetracycline. These results are in concordance with previous studies from Belgium, Spain and Iran, where the determined resistance rates for gentamicin and tetracycline were between 0 and $3.6 \%$ and $0-11 \%$, respectively $[55,56,59]$. In general, aminoglycosides (i.e. gentamicin, kanamycin and streptomycin) are highly effective against Arcobacter spp. and, therefore, are recommended for the treatment of severe infections [7]. However, in case of tetracycline, higher resistance rates (up to 90.5\%) were recently reported [23].

Azithromycin is more effective than erythromycin against Campylobacter, which is reflected in 16-fold lower ECOFF value. Both of these antibiotics belong to the class of macrolides; thus, the changes (i.e. methylation or mutations) in ribosomal target sites and drug efflux usually cause cross-resistance in Campylobacter spp. [60]. Surprisingly, Arcobacter spp. AST revealed equal or up to 16 times higher azithromycin MIC values in comparison with those of erythromycin for 145 (69.7\%; data not shown) isolates. Furthermore, MIC data for azithromycin were distributed bimodally, while an unimodal distribution for erythromycin was found. After applying C. coli EUCAST breakpoints, Van den Abeele et al. [56] found that 21.7\% (23/106) of the Arcobacter strains were resistant to erythromycin. This finding is in agreement with our results, as 42 isolates $(20.2 \%)$ had MICs $>8 \mu \mathrm{g} / \mathrm{ml}$. According to other authors, from 2.8 to $100 \%$ of tested Arcobacter strains were resistant toward this antibiotic [59, 61]. High resistance rates pose a serious risk to public health as erythromycin is critically 
important for treatment of campylobacteriosis and it was suggested to be used in Arcobacter infections [62]. As described in previous studies, we also found that the majority of azithromycin MICs (96.2\%) were equal to or above the C. jejuni ECOFF $(0.25 \mu \mathrm{g} / \mathrm{ml})[19,56]$. MIC data for azithromycin indicated the presence of a subpopulation with reduced susceptibility. Therefore, elevated MICs $(\geq 8 \mu \mathrm{g} / \mathrm{ml})$ were determined for $130(67.7 \%)$ A. butzleri and $2(12.5 \%)$ A. cryaerophilus strains. Similarly, Brückner et al. [19] observed elevated MIC values (> $8 \mu \mathrm{g} / \mathrm{ml}$ ) for $54.2 \%$ A. butzleri and $10 \%$ A. cryaerophilus strains. Divergent MIC distribution patterns for macrolides are consistent with the results of a recent study from Germany that tested the in vitro susceptibility of clinical Arcobacter strains using the same methodology [19]. Additionally, erythromycin MIC values peaked at $4 \mu \mathrm{g} / \mathrm{ml}$, while azithromycin MIC distribution was characterized by two peaks at $1 \mu \mathrm{g} / \mathrm{ml}$ and $16 \mu \mathrm{g} / \mathrm{ml}$, which is also in agreement with our results. The authors have hypothesized that an amino acid substitution (A86E) in ribosomal protein L22 and the absence of mutations (A2074T or A2075G) in $23 \mathrm{~S}$ rRNA gene may result in resistance to azithromycin and susceptibility to erythromycin, which is seen in Campylobacter [19, 63]. AST of clinical Legionella pneumophila strains showed that there is a correlation between reduced susceptibility to azithromycin and the presence of the lpeAB genes encoding a macrolide efflux pump [64]. Although Arcobacter spp. do not possess these genes, the presence of lpe $A B$ functional homologs (encoding MacAB-TolC) was already reported [58]. However, whole genome sequence-based analysis of Arcobacter is needed in order to determine the genetic mechanisms affecting the MICs of different macrolides.

According to EFSA and ECDC [54], ciprofloxacin resistance increased during the period from 2015 to 2019 in C. jejuni strains isolated from humans. In 2019, the reported resistance at EU level for $C$. jejuni and C. coli from various sources (i.e. humans, poultry, broiler meat) was between 61.5 and $90 \%$ and $61.2-89.4 \%$, respectively. In comparison with Campylobacter, the resistance rates in Arcobacter are lower (ranging from 0 to 27.4\%) [24, 56, 57]. Results of this study are in accordance with previous reports as only 18 (8.7\%) Arcobacter isolates had elevated MICs $(\geq 8 \mu \mathrm{g} / \mathrm{ml})$, while the rest displayed low values that ranged between 0.032 and $1 \mu \mathrm{g} / \mathrm{ml}$. The majority of strains (16/18) that had elevated MIC values were isolated from chicken meat. This result can be explained by the use of fluoroquinolones in poultry rearing [23]. A slightly higher percentage of $A$. butzleri isolates (8.9\%) showed reduced susceptibility in comparison to A. cryaerophilus (6.3\%), which is in line with a study by Rahimi et al. [59]. In case of ampicillin, high MICs $(\geq 24 \mu \mathrm{g} / \mathrm{ml})$ were determined for $46.9 \%$ of $A$. butzleri isolates, while only one A. cryaerophilus strain (6.3\%) showed a MIC of $24 \mu \mathrm{g} / \mathrm{ml}$. This result is in agreement with previous studies reporting high MICs for A. butzleri and A. cryaerophilus strains with rates of $42-100 \%$ and $0-23.3 \%$, respectively $[17,19,56]$. Furthermore, a majority $(23 / 30$, $76.7 \%$ ) of $A$. butzleri strains isolated from environmental water showed MICs that ranged from $24 \mu \mathrm{g} / \mathrm{ml}$ to > $256 \mu \mathrm{g} / \mathrm{ml}$. High rates of resistance $(94.4-100 \%)$ were observed in previous studies involving $A$. butzleri isolates from aquatic environment $[24,65]$.

According to our results, in case of ciprofloxacin, the $C$. jejuni ECOFF $(0.5 \mu \mathrm{g} / \mathrm{ml})$ could be applied for Arcobacter as isolates with MICs ranging from 0.032 to $0.5 \mu \mathrm{g} /$ $\mathrm{ml}$ formed a wild-type subpopulation (i.e. bacteria without acquired resistance mechanisms). This result is in agreement with previous reports $[19,66]$. However, for gentamicin, tetracycline, erythromycin, azithromycin and ampicillin, various rates of presumptive wild-type isolates (i.e. 35.6\%, 70.2\%, 39.6\%, 89.5\% and 66\%, respectively; Fig. 1) had MICs that were above the ECOFF values for C. jejuni. Therefore, Arcobacter ECOFFs for these antimicrobials may be higher and should be reassessed.

\section{Prevalence of putative virulence genes}

Although A. butzleri and A. cryaerophilus are considered as emerging zoonotic pathogens, data on virulence and pathogenic mechanisms is still limited [7]. The prevalence rates of putative virulence genes among Arcobacter spp. isolated from human, water and food samples were previously reported by several authors $[25,43,67,68]$. However, this is the first study reporting the occurrence of virulence genes in Arcobacter strains isolated from different sources in Lithuania.

We examined $A$. butzleri and A. cryaerophilus isolates for the presence of ten genes ( $m v i N, c a d F, c j 1349$, ciaB, pldA, hecA, hecB, tlyA, irgA and iroE) that are homologous to virulence factors in $C$. jejuni and other pathogens. The $m v i N$ gene encodes a protein essential for peptidoglycan biosynthesis. Genes $c a d F$ and $c j 1349$ encode outer membrane proteins, which promote the binding of bacteria to intestinal epithelial cells, while Campylobacter invasive antigen $\mathrm{B}(\mathrm{CiaB})$ contributes to host cell invasion. The hecA encodes for an adhesin of the filamentous hemagglutinin family. Three genes, namely pldA (encoding the outer membrane phospholipase $\mathrm{A})$, hecB (encoding hemolysin activation protein) and $t l y A$ (encoding hemolysin), are associated with lysis of erythrocytes. Genes $\operatorname{irg} A$ and $i r o E$ encode functional components (iron-regulated outer membrane protein and periplasmic enzyme) of iron acquisition system and therefore are required for establishing and maintaining infections [28]. However, it is still unknown whether Arcobacter spp. putative virulence factors have functions 
similar to those of their homologues in other pathogens. Regardless of isolation source, six genes, namely ciaB, $m v i N$, pldA, tlyA, cj1349 and cadF, were identified in most or even all A. butzleri isolates (100, 97.9, 95.8, 99, 99 and 100\%, respectively). The high occurrence of these genes (ranging between 77.5 and 100\%) was reported in previous studies after testing A. butzleri isolates from human stool, food products and in-line milk filters of cow dairy farms $[22,25,67,69]$. The remaining four genes, i.e., hecA, hecB, $\operatorname{irg} A$ and $\operatorname{iro} E$, were less prevalent. Higher cadF, ciaB, cj1349, mviN, pldA and tlyA detection rates in comparison with $\operatorname{irg} A, \operatorname{iro} E$, hecA, and $h e c B$ are consistent between most of published studies [22, $67,68,70]$. In general, the $\operatorname{irg} A$ gene showed the lowest occurrence rate (12.5\%) and was not detected in isolates from human stool, raw cow milk, and RTE salad mixes. Similar prevalence rates (ranging from 7.1 to $17.6 \%$ ) were reported previously [22, 55, 69]. The presence of $\operatorname{irgA}$ gene in A. butzleri from raw cow milk and RTE vegetables was rarely investigated; however, Girbau et al. [67] and Mottola et al. [42] did not detect irgA in strains that were isolated from these sources, which is in line with our study. The occurrence of hecA (20.3\%), hecB (38.5\%) and $\operatorname{iro} E(18.8 \%)$ genes is similar to that reported by other authors (ranging between 10.8 and 31.3, 29-38.8 and $12-30 \%$, respectively) $[22,25,69,71]$. Surprisingly, the presence of $h e c A, \operatorname{irgA}$ and $\operatorname{iroE}$ was considerably lower in human stool and food isolates compared with environmental water isolates. This is in agreement with Karadas et al. [68] who determined higher detection rates for $\operatorname{irg} A$ (44\%), hecA (44\%) and iroE (67\%) in isolates from water in comparison to isolates originating from humans, pork, chicken meat, and minced meat. However, in contrast to Karadas et al. [68], our results revealed that the gene encoding hemolysin activation protein (hecB) was significantly more prevalent in strains from water and human clinical samples compared with strains from food $(\mathrm{P}<$ 0.05). This difference might be associated with the lower number of isolates tested in previous study. Fourteen $A$. butzleri isolates $(7.3 \%)$, obtained from chicken meat ( $\mathrm{n}$ $=7 ; 6.1 \%)$ and environmental water $(\mathrm{n}=7 ; 23.3 \%)$, were found to carry all ten putative virulence genes. Slightly different rates (ranging from 1.7 to $22.5 \%$ ) were determined in studies from Spain and Germany [67, 72]. This disparity might be due to differences in the origin of tested isolates.

In accordance with other reports [25, 42, 48, 67], we observed fewer virulence genes $(\mathrm{n}=5)$ among $A$. cryaerophilus strains in comparison to A. butzleri. For $A$. cryaerophilus, irrespective of origin, two genes (ciaB and $m v i N)$ were detected in all isolates, whereas cj1349 and hec $A$ were present in $12.5 \%$, and tly $A$ in $25 \%$ of isolates. The predominance of $c i a B$ and $m v i N$ in $A$. cryaerophilus was reported in previous studies involving isolates from poultry meat, water and other sources $[25,71]$. For bacteria originating from vegetables, the data on virulence gene distribution is limited to one study, which showed partial agreement with our results. In particular, the study from Italy reported the presence of $c a d F$ and $m v i N$ in all $A$. cryaerophilus isolates, while other seven genes (i.e. $\operatorname{cia} B, c j 1349$, $\operatorname{irg} A$, hecA, tly $A$, hecB and pldA) were not detected [42]. According to other authors, the occurrence of $c j 1349$, hecA and tlyA in A. cryaerophilus varies greatly with rates ranging between 0 and $76.9 \%, 0-30 \%$, and $0-31.8 \%$ respectively $[42,67,73]$. Furthermore, $c a d F$ (6.8-61.5\%), pldA (16.9-61.5\%) and $\operatorname{irgA}(2.6-15.9 \%)$ were also identified in $A$. cryaerophilus [43, 70, 73]; however, we did not detect these genes among tested isolates. The above-mentioned virulence profile differences within A. cryaerophilus species might be associated with higher genomic heterogeneity in primer target sequences [70].

\section{Conclusions}

In conclusion, the data of this study provide first insight into the prevalence, antimicrobial susceptibility and putative virulence gene profiles of Arcobacter spp. from inpatients, foods of animal origin (chicken meat and raw cow milk), ready-to-eat (RTE) salad mixes and environmental water in Lithuania. High contamination rates of meat, milk, water and, to a lesser extent, RTE salad mixes, and the presence of multiple virulence genes in isolated Arcobacter, highlights their potential role in the epidemiology of Arcobacter infections. Moreover, according to our results, Arcobacter should be considered as an etiological factor for human gastroenteritis. Fluoroquinolones and aminoglycosides were found to be more effective against $A$. butzleri, and A. cryaerophilus in comparison with macrolides, tetracyclines, and aminopenicillins. Antimicrobial susceptibility testing also revealed different distribution patterns of minimal inhibitory concentration for macrolides (azithromycin and erythromycin). However, further in vitro, in vivo and in silico whole genome sequence-based studies are needed in order to (i) identify genetic mechanisms causing reduced susceptibility to antimicrobial agents, (ii) to determine the potential role of tested virulence factors in the pathogenesis of Arcobacter infection, and (iii) to clarify the epidemiological situation in other geographic regions.

\section{Methods}

\section{Sample collection}

In this study, a total of 1862 samples were collected in the city of Kaunas, Lithuania. As it is summarized in Table 1, human stool, chicken meat, raw cow milk and environmental water samples were collected during a 12-month survey, while RTE salad mixes were tested for 11 months. 
In total, 1200 human stool samples were collected by Kaunas Clinical Hospital Microbiology Laboratory for the detection of Arcobacter spp. Stool samples were collected prior to antimicrobial treatment from inpatients with symptoms of gastroenteritis. All participants were de-identified by pseudonymization. Therefore, patient data (including medical history) were not accessible. Chicken meat ( $\mathrm{n}=331$, including drumsticks and wings), raw cow milk $(\mathrm{n}=104)$ and RTE salad mixes $(\mathrm{n}=99)$ were purchased from different randomly selected retail establishments. Sampling of surface waters $(\mathrm{n}=128$, including lake and river water) was performed along public beach sites using sterile $50 \mathrm{ml}$ conical tubes. Food and water samples were transported to the laboratory and processed within 2 to $4 \mathrm{~h}$ of collection. Stool samples were transported from the clinical microbiology laboratory and tested for the presence of Arcobacter spp. within 7 days of collection.

\section{Isolation of Arcobacter spp}

Depending on the sample type, two different approaches were used for the detection of Arcobacter. Isolation of Arcobacter spp. from human clinical samples was carried out using selective enrichment method described by van Driessche et al. [74]. Briefly, $1 \mathrm{~g}$ of feces per sample was transferred to sterile test tubes and diluted with $9 \mathrm{ml}$ (1:10 dilution) of selective enrichment broth containing Arcobacter broth (Oxoid, Thermo Fisher Scientific, Basingstoke, United Kingdom) (24 g/l), 50 ml/l lysed horse blood (Oxoid, Thermo Fisher Scientific), amphotericin B $(10 \mathrm{mg} / \mathrm{l})$, cefoperazone $(16 \mathrm{mg} / \mathrm{l})$, novobiocin $(32 \mathrm{mg} / \mathrm{l})$, trimethoprim (64 mg/l) and 5-fluorouracil (100 mg/l) (all Sigma-Aldrich, Steinheim, Germany). Then, the samples were mixed using a vortex mixer and incubated for $72 \mathrm{~h}$ at $30{ }^{\circ} \mathrm{C}$ in a microaerobic atmosphere. Microaerobic conditions were produced using CampyGen gas packs (Oxoid, Thermo Fisher Scientific). After incubation, $50 \mu \mathrm{l}$ of enrichment broth was streaked onto Arcobacter selective agar plates (same composition as described above, with the exception of lysed horse blood) and incubated for $48 \mathrm{~h}\left(30{ }^{\circ} \mathrm{C}\right.$, microaerobic conditions). Typical Arcobacter colonies (small, circular with entire margins, convex and whitish-gray) were subcultured onto MuellerHinton agar (Oxoid, Thermo Fisher Scientific) plates supplemented with $50 \mathrm{ml} / \mathrm{l}$ defibrinated sheep blood (MHB) (Oxoid, Thermo Fisher Scientific) and incubated for $48 \mathrm{~h}$ $\left(30^{\circ} \mathrm{C}\right.$, microaerobic conditions).

Isolation of Arcobacter spp. from food products and water was performed using membrane filtration method as previously described by Atabay et al. [75]. Prior to enrichment, water samples were centrifuged $(3,500 \mathrm{x}$ $\mathrm{g}$ for $10 \mathrm{~min}$ ) and pellets were resuspended in $10 \mathrm{ml}$ of Arcobacter broth (AB) with selective supplement containing cefoperazone $(8 \mathrm{mg} / \mathrm{l})$, amphotericin B $(10 \mathrm{mg} / \mathrm{l})$ and teicoplanin $(4 \mathrm{mg} / \mathrm{l})$ (CAT, Oxoid, Thermo Fisher Scientific). Each food sample $(1 \mathrm{~g}$ or $1 \mathrm{ml})$ was added to $A B / C A T$ at a ratio of 1:10. Subsequently, all samples were thoroughly mixed and incubated for $48 \mathrm{~h}$ at $30{ }^{\circ} \mathrm{C}$ under microaerobic conditions. Following incubation, $300 \mu \mathrm{l}$ from each enriched sample was transferred onto a $0.45 \mu \mathrm{m}$ pore size mixed cellulose ester membrane filter (Frisenette, Knebel, Denmark) placed on the surface of MHB agar. After $1 \mathrm{~h}$ of passive filtration $\left(30^{\circ} \mathrm{C}\right.$, aerobic conditions), the filters were aseptically removed and plates were incubated at $30{ }^{\circ} \mathrm{C}$ in a microaerobic atmosphere. The plates were checked every $24 \mathrm{~h}$ (up to 7 days) for the presence of typical Arcobacter colonies. From each plate, five suspected colonies were subcultured onto MHB plates for $48 \mathrm{~h}$ at $30{ }^{\circ} \mathrm{C}$ in microaerobic conditions.

\section{Molecular identification and verification of Arcobacter isolates}

Template DNA of presumptive Arcobacter isolates was prepared using PrepMan ${ }^{\circledR}$ Ultra Reagent (Applied Biosystems, Woolston, Warrington, United Kingdom) according to the manufacturer's specifications. Isolates were identified at species level using multiplex polymerase chain reaction (mPCR) previously described by Houf et al. [76]. Primers targeting $23 \mathrm{~S}$ and $16 \mathrm{~S}$ rRNA genes for the simultaneous identification of $A$. cryaerophilus, A. butzleri and A. skirrowii were used (Table 5). Amplification reaction mixture contained $2 \mu \mathrm{l}$ template DNA, $12.5 \mu$ l of DreamTaq ${ }^{\text {TM }}$ Green PCR Master Mix (2x) (Thermo Fisher Scientific, Vilnius, Lithuania), $1 \mu \mathrm{M}$ of each primer ARCO R, BUTZ F, CRY 1, CRY 2, $0.5 \mu \mathrm{M}$ of primer SKIR F and $8.25 \mu \mathrm{l}$ of molecular grade water (Thermo Fisher Scientific) in a total reaction volume of $25 \mu \mathrm{l}$. Prior to cycling, samples underwent initial denaturation step at $94{ }^{\circ} \mathrm{C}$ for $2 \mathrm{~min}$. This step was followed by 32 PCR cycles, consisting of denaturation at $94{ }^{\circ} \mathrm{C}$ for $45 \mathrm{~s}$, annealing at $61{ }^{\circ} \mathrm{C}$ for $45 \mathrm{~s}$ and extension at $72{ }^{\circ} \mathrm{C}$ for $30 \mathrm{~s}$ and a final elongation step at $72{ }^{\circ} \mathrm{C}$ for $5 \mathrm{~min}$. DNA of $A$. butzleri (ATCC 49,616), A. cryaerophilus (ATCC 43,158) and A. skirrowii (ATCC 51,132) were used as positive control, while molecular grade water (Thermo Fisher Scientific) was used as negative control. Separation of amplification products was performed using horizontal electrophoresis in $2 \%$ agarose in 1xTris-Borate-EDTA (TBE) buffer. The gels were stained with ethidium bromide and visualized under UV light.

Verification of identified isolates was ensured by $г р о B$ gene sequencing previously described by Korczak et al. [77]. Briefly, $r p o B$ gene amplification was performed in a $50 \mu \mathrm{l}$ PCR-mixture containing $4 \mu \mathrm{l}$ of template DNA, $1 \mathrm{x}$ PCR buffer, $0.75 \mathrm{U}$ of Taq polymerase, $0.2 \mathrm{mM}$ of each deoxynucleoside triphosphate (dNTP), $2.5 \mathrm{mM}$ 
Table 5 List of primers used in this study

\begin{tabular}{|c|c|c|c|c|}
\hline Target gene & Primer pair & Primer sequence $\left(5^{\prime}-3^{\prime}\right)$ & Amplicon size (bp) & References \\
\hline \multicolumn{5}{|c|}{ Species identification } \\
\hline A. butzleri & BUTZF & CCTGGACTTGACATAGTAAGAATGA & \multirow[t]{2}{*}{401} & \multirow[t]{6}{*}{ Houf et al. [76] } \\
\hline $16 \mathrm{~S} r \mathrm{RNA}$ & ARCOR & CGTATTCACCGTAGCATAGC & & \\
\hline A. skirrowii & SKIR F & GGCGATTTACTGGAACACA & \multirow[t]{2}{*}{641} & \\
\hline $16 \mathrm{SrRNA}$ & ARCO R & CGTATTCACCGTAGCATAGC & & \\
\hline A. cryaerophilus & CRY1 & TGCTGGAGCGGATAGAAGTA & \multirow[t]{2}{*}{257} & \\
\hline $23 \mathrm{~S} r \mathrm{RNA}$ & CRY2 & AACAACCTACGTCCTTCGAC & & \\
\hline \multicolumn{5}{|l|}{ Verification } \\
\hline \multirow[t]{2}{*}{$r p o B$} & CamrpoB-L & CCAATTTATGGATCAAAC & \multirow[t]{2}{*}{524} & \multirow[t]{2}{*}{ Korczak et al. [77] } \\
\hline & RpoB-R & GTTGCATGTTNGNACCCAT & & \\
\hline \multicolumn{5}{|c|}{ Detection of putative virulence genes } \\
\hline \multirow{2}{*}{ mviN } & mviN-F & TGCACTTGTTGCAAAACGGTG & \multirow[t]{2}{*}{294} & \multirow[t]{2}{*}{ Whiteduck-Leveillee et al. [78] } \\
\hline & mviN-R & TGCTGATGGAGCTTTTACGCAAGC & & \\
\hline \multirow[t]{2}{*}{ cadF } & cadF-F & TTACTCCTACACCGTAGT & \multirow[t]{2}{*}{283} & \multirow[t]{2}{*}{ Douidah et al. [70] } \\
\hline & cadF-R & AAACTATGCTAACGCTGGTT & & \\
\hline \multirow[t]{2}{*}{ cj1349 } & cj1349-F & CCAGAAATCACTGGCTTTTGAG & \multirow[t]{2}{*}{659} & \multirow[t]{2}{*}{ Whiteduck-Leveillee et al. [78] } \\
\hline & cj1349-R & GGGCATAAGTTAGATGAGGTTCC & & \\
\hline \multirow[t]{2}{*}{$c i a B$} & ciaB-F & TGGGCAGATGTGGATAGAGCTTGGA & \multirow[t]{2}{*}{284} & \\
\hline & ciaB-R & TAGTGCTGGTCGTCCCACATAAAG & & \\
\hline \multirow[t]{2}{*}{ pldA } & pldA-F & TTGACGAGACAATAAGTGCAGC & \multirow[t]{2}{*}{293} & \\
\hline & pldA-R & CGTCTTTATCTTTGCTTTCAGGGA & & \\
\hline \multirow[t]{2}{*}{ hecA } & hecA-F & GTGGAAGTACAACGATAGCAGGCTC & \multirow[t]{2}{*}{537} & \\
\hline & hecA-R & GTCTGTTTTAGTTGCTCTGCACTC & & \\
\hline \multirow[t]{2}{*}{ hecB } & hecB-F & CTAAACTCTACAAATCGTGC & \multirow[t]{2}{*}{528} & \\
\hline & hecB-R & CTTTTGAGTGTTGACCTC & & \\
\hline \multirow[t]{2}{*}{ tlyA } & tlyA-F & CAAAGTCGAAACAAAGCGACTG & \multirow[t]{2}{*}{230} & \\
\hline & tlyA-R & TCCACCAGTGCTACTTCCTATA & & \\
\hline \multirow[t]{2}{*}{$\operatorname{irg} A$} & $\operatorname{irg} A-F$ & TGCAGAGGATACTTGGAGCGTAACT & \multirow[t]{2}{*}{437} & \\
\hline & $\operatorname{irg} A-R$ & GTATAACCCCATTGATGAGGAGCA & & \\
\hline iroE & iroE-F & AATGGCTATGATGTTGTTTAC & 415 & Karadas et al. [68] \\
\hline & iroE-R & TTGCTGCTATGAAGTTTTG & & \\
\hline
\end{tabular}

of $\mathrm{MgCl}_{2}$ (all from Thermo Fisher Scientific), $0.4 \mu \mathrm{M}$ of each primer CamrpoB-L and RpoB-R. Before cycling, samples were subjected to initial denaturation step at $95{ }^{\circ} \mathrm{C}$ for $3 \mathrm{~min}$. PCR involved 35 cycles with following conditions: denaturation at $94{ }^{\circ} \mathrm{C}$ for $30 \mathrm{~s}$, annealing at $54{ }^{\circ} \mathrm{C}$ for $30 \mathrm{~s}$ and extension at $72{ }^{\circ} \mathrm{C}$ for $30 \mathrm{~s}$. Last cycle was followed by a final elongation step at $72{ }^{\circ} \mathrm{C}$ for 5 min. Amplified products were separated and visualized as described above. Purification of PCR products was performed using GeneJET PCR Purification Kit (Thermo Fisher Scientific) according to manufacturer's specifications. Around $30 \mathrm{ng}$ purified PCR products were sequenced by GATC (Eurofins GATC Biotech, Konstanz, Germany). Identification of species was performed by comparing query $r p o B$ sequences with BLAST database (NCBI).

\section{Antimicrobial susceptibility testing}

All identified and verified isolates were tested for susceptibility to six antimicrobial agents (azithromycin, ampicillin, ciprofloxacin, gentamicin, erythromycin and tetracycline) by gradient strip diffusion method (E-test $^{\mathrm{TM}}$, bioMérieux, Nürtingen, Germany). The AST assays were performed according to the manufacturer's instructions with minor modifications. Briefly, Arcobacter isolates were grown on MHB agar plates under microaerobic atmosphere for $48 \mathrm{~h}$ at $30{ }^{\circ} \mathrm{C}$. A small amount of colony material from every plate was transferred to tubes with $2 \mathrm{ml}$ of Brucella broth (BB) (Biolife, Milan, Italy) and incubated overnight $\left(30^{\circ} \mathrm{C}\right)$ under microaerobic conditions. These precultures were used to achieve an inoculum of approximately $1 \times 10^{8}$ colony forming units (CFU) per ml. Because of the slow growth of A. cryaerophilus isolates, three overnight cultures per isolate were 
prepared. After overnight incubation all cultures from one isolate were pooled $(6 \mathrm{ml})$, centrifuged $(16,000 \mathrm{xg}$ for $5 \mathrm{~min}$ ) and the pellets were resuspended in $0.6 \mathrm{ml}$ of BB to yield analogous inoculum concentrations. Escherichia coli ATCC 25,922 was used as a quality control in every test run (cultured on MHB for $48 \mathrm{~h}$ and precultured overnight in $\mathrm{BB}$ for $24 \mathrm{~h}$ at $37^{\circ} \mathrm{C}$ in an aerobic atmosphere). Test strips were applied to MHB agar plates after inoculating them with $100 \mu \mathrm{l}$ of overnight culture. Minimum inhibitory concentrations (MICs) were determined after $48 \mathrm{~h}$ incubation at $30{ }^{\circ} \mathrm{C}$ under microaerobic conditions $\left(37^{\circ} \mathrm{C}\right.$ and aerobic atmosphere for the reference strain of E. coli). Only agar plates with a confluent bacterial lawn were evaluated.

\section{Detection of virulence genes}

The presence of ten putative Arcobacter virulence genes was determined by PCR. All primers used are listed in Table 4. PCR protocols for partial amplification of cj1349, ciaB, mviN, pldA, tlyA, irgA, hecA and hecB were used as previously described by Whiteduck-Leveillee et al. [78]. Briefly, PCR assay was carried out in $25 \mu \mathrm{l}$ volume reaction mixture containing $2 \mu \mathrm{l}$ template DNA, $12.5 \mu \mathrm{l}$ of DreamTaq $^{\mathrm{TM}}$ Green PCR Master Mix (2x) and $0.1 \mu \mathrm{M}$ of each forward and reverse primer. PCR conditions were as follows: initial denaturation $\left(95^{\circ} \mathrm{C}\right.$ for $\left.4 \mathrm{~min}\right), 30$ cycles of amplification (denaturation at $95^{\circ} \mathrm{C}$ for $30 \mathrm{~s}$, annealing at $56{ }^{\circ} \mathrm{C}$ for $45 \mathrm{~s}$ and extension at $72{ }^{\circ} \mathrm{C}$ for $45 \mathrm{~s}$ ) and final elongation $\left(72{ }^{\circ} \mathrm{C}\right.$ for $\left.5 \mathrm{~min}\right)$. Partial amplification of $c a d F$ and $\operatorname{iroE}$ was carried out using the protocol described by Karadas et al. [68]. The reaction mixture was of the same composition as described above, except that primers were used at $1 \mu \mathrm{M}$. The reaction involved initial denaturation $\left(95^{\circ} \mathrm{C}\right.$ for $4 \mathrm{~min}$ ), followed by 30 cycles of amplification $\left(95^{\circ} \mathrm{C}\right.$ for $30 \mathrm{~s}, 50{ }^{\circ} \mathrm{C}$ for $30 \mathrm{~s}$ and $72{ }^{\circ} \mathrm{C}$ for $30 \mathrm{~s})$ and ended up with a final elongation step $\left(72{ }^{\circ} \mathrm{C}\right.$ for $5 \mathrm{~min})$. Amplification products were separated by horizontal electrophoresis in $2 \%$ agarose in $1 \mathrm{xTBE}$ buffer. The gels were stained with ethidium bromide. The presence of fragments was checked under a UV trans-illuminator.

\section{Statistical analysis}

Data were analyzed by using Microsoft Office Excel 2016 (Microsoft Corp., Redmond, WA, US) and IBM SPSS Statistics 26.0 software package (IBM Corp., Armonk, NY, US). The Pearson's chi-squared test and Fisher's exact test were performed in order to compare the differences between prevalence rates, and to analyze the association of the ten putative virulence genes in Arcobacter isolates with their biological origin. In both cases, statistical hypotheses were tested between two sources (in various combinations) and differences were considered significant if $\mathrm{P}<0.05$.
Acknowledgements

Not applicable.

\section{Authors' contributions}

DU, GG and MM designed the concept of this study. TA and ET provided advice in study design. DU, GG and AG carried out the experimental work and analysis. DU performed statistical analysis and drafted the manuscript. GG assisted in drafting the manuscript. MM, AG, ET and TA contributed to the interpretation of results and co-edited the manuscript. MM and TA coordinated the whole project. All authors read and approved the final version of the manuscript.

\section{Funding}

This work was partially supported by the German Federal Ministries of Education and Research (BMBF) by grant 01 KI1712 (Arco-Path) and the BalticGerman University Liaison Office according to agreement No. 2021/8. The funders had no role in study design, data collection, analysis and interpretation, decision to publish, or preparation of the manuscript.

\section{Availability of data and materials}

All data generated or analyzed during this study are included in this published article.

\section{Declarations}

\section{Ethics approval and consent to participate}

The study involving human participants was reviewed and approved by the Kaunas Regional Biomedical Research Ethics Committee (Approval No.: BE-258). All stool samples were collected by Kaunas Clinical Hospital Microbiology Laboratory for routine diagnostic analysis. Prior to isolation and characterization of Arcobacter spp., patient data were de-identified using pseudonymization. Hence, no written informed consent to participate in this study was obtained.

\section{Consent for publication}

Not applicable.

\section{Competing interests}

The authors declare that they have no competing interests.

\section{Author details}

${ }^{1}$ Department of Food Safety and Quality, Faculty of Veterinary Medicine, Veterinary Academy, Lithuanian University of Health Sciences, Kaunas, Lithuania. ${ }^{2}$ Institute of Food Safety and Food Hygiene, Freie Universität Berlin, Berlin, Germany. ${ }^{3}$ Kaunas Clinical Hospital Microbiology Laboratory, Medical Academy, Lithuanian University of Health Sciences, Kaunas, Lithuania. ${ }^{4}$ Department of Pediatrics, Medical Academy, Lithuanian University of Health Sciences, Kaunas, Lithuania.

Received: 18 August 2021 Accepted: 7 December 2021

Published online: 20 December 2021

\section{References}

1. Vandamme P, Falsen E, Rossau R, Hoste B, Segers P, Tytgat R, et al. Revision of Campylobacter, Helicobacter, and Wolinella taxonomy: emendation of generic descriptions and proposal of Arcobacter gen. nov. Int J Syst Bacteriol. 1991;41(1):88-103.

2. Ferreira S, Oleastro M, Domingues F. Current insights on Arcobacter butzleri in food chain. Curr Opin Food Sci. 2019;26:9-17.

3. Pérez-Cataluña A, Salas-Massó N, Diéguez AL, Balboa S, Lema A, Romalde $J \mathrm{~L}$, et al. Revisiting the taxonomy of the genus Arcobacter: Getting order from the chaos. Front Microbiol. 2018;9:2077.

4. On SLW, Miller WG, Biggs PJ, Cornelius AJ, Vandamme P. A critical rebuttal of the proposed division of the genus Arcobacter into six genera using comparative genomic, phylogenetic, and phenotypic criteria. Syst Appl Microbiol. 2020:43(5):126108. 
5. Kerkhof PJ, Van den Abeele AM, Strubbe B, Vogelaers D, Vandamme P, Houf K. Diagnostic approach for detection and identification of emerging enteric pathogens revisited: the (Ali)arcobacter lanthieri case. New Microbes New Infect. 2021;39:100829.

6. Ramees TP, Dhama K, Karthik K, Rathore RS, Kumar A, Saminathan M, et al. Arcobacter: an emerging food-borne zoonotic pathogen, its public health concerns and advances in diagnosis and control-a comprehensive review. Vet Q. 2017;37(1):136-61.

7. Chieffi D, Fanelli F, Fusco V. Arcobacter butzleri: Up-to-date taxonomy, ecology, and pathogenicity of an emerging pathogen. Compr Rev Food Sci Food Saf. 2020;19(4):2071-109.

8. Collado L, Figueras MJ. Taxonomy, epidemiology, and clinical relevance of the genus Arcobacter. Clin Microbiol Rev. 2011;24(1):174-92.

9. Hsu TTD, Lee J. Global distribution and prevalence of Arcobacter in food and water. Zoonoses Public Health. 2015;62(8):579-89.

10. Niedermeyer JA, Miller WG, Yee E, Harris A, Emanuel RE, Jass T, et al. Search for Campylobacter spp. reveals high prevalence and pronounced genetic diversity of Arcobacter butzleri in floodwater samples associated with Hurricane Florence in North Carolina, USA. Appl Environ Microbiol. 2020;86:20.

11. Ferreira S, Queiroz JA, Oleastro M, Domingues FC. Insights in the pathogenesis and resistance of Arcobacter: a review. Crit Rev Microbiol. 2015;1-20.

12. Arguello E, Otto CC, Mead P, Babady NE. Bacteremia caused by Arcobacter butzleri in an immunocompromised host. J Clin Microbiol. 2015;53(4):1448-51.

13. Yap DYH, Kwan LPY, To KKW, Chan TM. Arcobacter peritonitis after fluoroscopic repositioning of a Tenckhoff catheter. Perit Dial Int J Int Soc Perit Dial. 2013;33(2):222-3.

14. Van den Abeele AM, Vogelaers D, Van Hende J, Houf K. Prevalence of Arcobacter species among humans, Belgium, 2008-2013. Emerg Infect Dis. 2014;20(10):1746-9.

15. Wybo I, Breynaert J, Lauwers S, Lindenburg F, Houf K. Isolation of Arcobacter skirrowii from a patient with chronic diarrhea. J Clin Microbiol. 2004:42(4):1851-2.

16. Samie A, Obi CL, Barrett $\sqcup$, Powell SM, Guerrant RL. Prevalence of Campylobacter species, Helicobacter pylori and Arcobacter species in stool samples from the Venda region, Limpopo, South Africa: studies using molecular diagnostic methods. J Infect. 2007;54(6):558-66.

17. Kayman T, Abay S, Hizlisoy H, Atabay Hi, Diker KS, Aydin F. Emerging pathogen Arcobacter spp. in acute gastroenteritis: molecular identification, antibiotic susceptibilities and genotyping of the isolated arcobacters. J Med Microbiol. 2012;61(10):1439-44.

18. Patyal A, Rathore RS, Mohan HV, Dhama K, Kumar A. Prevalence of Arcobacter spp. in humans, animals and foods of animal origin including sea food from India. Transbound Emerg Dis. 2011;58(5):402-10.

19. Brückner V, Fiebiger U, Ignatius R, Friesen J, Eisenblätter M, Höck M, et al. Prevalence and antimicrobial susceptibility of Arcobacter species in human stool samples derived from out- and inpatients: the prospective German Arcobacter prevalence study Arcopath. Gut Pathog. 2020;12(1):21

20. Figueras MJ, Levican A, Pujol I, Ballester F, Rabada Quilez MJ, GomezBertomeu F. A severe case of persistent diarrhoea associated with Arcobacter cryaerophilus but attributed to Campylobacter sp. and a review of the clinical incidence of Arcobacter spp. New Microbes New Infect. 2014;2(2):31-7.

21. Ferreira S, Luís Â, Oleastro M, Pereira L, Domingues FC. A meta-analytic perspective on Arcobacter spp. antibiotic resistance. J Glob Antimicrob Resist. 2019;16:130-9.

22. Rathlavath S, Kohli V, Singh AS, Lekshmi M, Tripathi G, Kumar S, et al. Virulence genotypes and antimicrobial susceptibility patterns of Arcobacter butzleri isolated from seafood and its environment. Int J Food Microbiol. 2017:263:32-7.

23. Vicente-Martins $S$, Oleastro M, Domingues FC, Ferreira S. Arcobacter spp. at retail food from Portugal: Prevalence, genotyping and antibiotics resistance. Food Control. 2018;85:107-12.

24. Šilha D, Pejchalová M, Šilhová L. Susceptibility to 18 drugs and multidrug resistance of Arcobacter isolates from different sources within the Czech Republic. J Glob Antimicrob Resist. 2017;9:74-7.

25. Brückner V, Fiebiger U, Ignatius R, Friesen J, Eisenblätter $M$, Höck M, et al. Characterization of Arcobacter strains isolated from human stool samples: results from the prospective German prevalence study Arcopath. Gut Pathog. 2020;12(1):3.

26. Ho HTK, Lipman LJA, Hendriks HGCJM, Tooten PCJ, Ultee T, Gaastra W. Interaction of Arcobacter spp. with human and porcine intestinal epithelial cells. FEMS Immunol Med Microbiol. 2007;50(1):51-8.

27. Bücker R, Troeger H, Kleer J, Fromm M, Schulzke J. Arcobacter butzleri induces barrier dysfunction in intestinal HT-29/B6 cells. J Infect Dis. 2009;200(5):756-64

28. Miller WG, Parker CT, Rubenfield M, Mendz GL, Wösten MMSM, Ussery DW, et al. The complete genome sequence and analysis of the Epsilonproteobacterium Arcobacter butzleri. PLoS ONE. 2007;2(12):e1358.

29. European Committee on Antimicrobial Susceptibility Testing. Data from the EUCAST MIC distribution website. 2021. https://www.eucast.org. Accessed 10 Mar 2021.

30. International Commission on Microbiological Specifications for Foods (ICMSF), Tompkin RB, editors. Microorganisms in foods 7: microbiological testing in food safety management. New York: Kluwer Academic/Plenum Publishers; 2002. p. 171.

31. Ferreira S, Júlio C, Queiroz JA, Domingues FC, Oleastro M. Molecular diagnosis of Arcobacter and Campylobacter in diarrhoeal samples among Portuguese patients. Diagn Microbiol Infect Dis. 2014;78(3):220-5.

32. Fernandez H, Villanueva MP, Mansilla I, Gonzalez M, Latif F. Arcobacter butzleri and $A$. cryaerophilus in human, animals and food sources, in southern Chile. Braz J Microbiol. 2015;46(1):145-7.

33. Vandenberg O, Dediste A, Houf K, Ibekwem S, Souayah H, Cadranel S, et al. Arcobacter species in humans. Emerg Infect Dis. 2004;10(10):1863-7.

34. Shange N, Gouws P, Hoffman LC. Campylobacter and Arcobacter species in food-producing animals: prevalence at primary production and during slaughter. World J Microbiol Biotechnol. 2019;35(9):146.

35. Nieva-Echevarria B, Martinez-Malaxetxebarria I, Girbau C, Alonso R, Fernández-Astorga A. Prevalence and genetic diversity of Arcobacter in food products in the north of Spain. J Food Prot. 2013;76(8):1447-50.

36. Shah AH, Saleha AA, Zunita Z, Murugaiyah M. Arcobacter-an emerging threat to animals and animal origin food products? Trends Food Sci Technol. 2011;22(5):225-36.

37. Amare LB, Saleha AA, Zunita Z, Jalila A, Hassan L. Prevalence of Arcobacter spp. on chicken meat at retail markets and in farm chickens in Selangor, Malaysia. Food Control. 2011;22(5):732-6.

38. Traversa A, Gallina S, Martucci F, Boteva C, Baioni E, Maurella C, et al. Arcobacter spp. in raw milk from vending machines in Piedmont and occurrence of virulence genes in isolates. Ital J Food Saf. 2019;8(4):7859.

39. Zacharow I, Bystroń J, Wałecka-Zacharska E, Podkowik M, Bania J. Prevalence and antimicrobial resistance of Arcobacter butzleri and Arcobacter cryaerophilus isolates from retail meat in Lower Silesia region, Poland. Pol J Vet Sci. 2015;18(1):63-9.

40. Marta C, Giovanni N, Angela M, Loredana C, Elisabetta B, Laura D, et al. Large genetic diversity of Arcobacter butzleri isolated from raw milk in Southern Italy. Food Microbiol. 2020;89:103403.

41. Scullion R, Harrington CS, Madden RH. Prevalence of Arcobacter spp. in raw milk and retail raw meats in Northern Ireland. J Food Prot. 2006;69(8):1986-90.

42. Mottola A, Bonerba E, Bozzo G, Marchetti P, Celano GV, Colao V, et al. Occurrence of emerging food-borne pathogenic Arcobacter spp. isolated from pre-cut (ready-to-eat) vegetables. Int J Food Microbiol. 2016;236:33-7.

43. Kim NH, Park SM, Kim HW, Cho TJ, Kim SH, Choi C, et al. Prevalence of pathogenic Arcobacter species in South Korea: Comparison of two protocols for isolating the bacteria from foods and examination of nine putative virulence genes. Food Microbiol. 2019;78:18-24.

44. Assanta MA, Roy D, Lemay M-J, Montpetit D. Attachment of Arcobacter butzleri, a new waterborne pathogen, to water distribution pipe surfaces. J Food Prot. 2002;65(8):1240-7.

45. Kjeldgaard J, Jørgensen K, Ingmer H. Growth and survival at chiller temperatures of Arcobacter butzleri. Int J Food Microbiol. 2009;131 (2-3):256-9.

46. Rasmussen L, Kjeldgaard J, Christensen J, Ingmer H. Multilocus sequence typing and biocide tolerance of Arcobacter butzleri from Danish broiler carcasses. BMC Res Notes. 2013;6(1):322.

47. Webb AL, Taboada EN, Selinger LB, Boras VF, Inglis GD. Prevalence and diversity of waterborne Arcobacter butzleri in southwestern Alberta, Canada. Can J Microbiol. 2017;63(4):330-40. 
48. Laishram M, Rathlavath S, Lekshmi M, Kumar S, Nayak BB. Isolation and characterization of Arcobacter spp. from fresh seafood and the aquatic environment. Int J Food Microbiol. 2016;232:87-9.

49. Collado L, Inza I, Guarro J, Figueras MJ. Presence of Arcobacter spp. in environmental waters correlates with high levels of fecal pollution. Environ Microbiol. 2008;10(6):1635-40.

50. Collado L, Kasimir G, Perez U, Bosch A, Pinto R, Saucedo G, et al. Occurrence and diversity of Arcobacter spp. along the Llobregat River catchment, at sewage effluents and in a drinking water treatment plant. Water Res. 2010;44(12):3696-702.

51. Rathlavath S, Kumar S, Nayak BB. Comparative isolation and genetic diversity of Arcobacter sp. from fish and the coastal environment. Lett Appl Microbiol. 2017;65(1):42-9.

52. Fallas-Padilla KL, Rodríguez-Rodríguez CE, Jaramillo HF, Echandi MLA. Arcobacter: comparison of isolation methods, diversity, and potential pathogenic factors in commercially retailed chicken breast meat from Costa Rica. J Food Prot. 2014;77(6):880-4.

53. Scullion R, Harrington CS, Madden RH. A comparison of three methods for the isolation of Arcobacter spp. from retail raw poultry in Northern Ireland. J Food Prot. 2004;67(4):799-804.

54. European Food Safety Authority, European Centre for Disease Prevention and Control. The European Union Summary Report on Antimicrobial Resistance in zoonotic and indicator bacteria from humans, animals and food in 2018/2019. EFSA J. 2021;19(4):6490

55. Pérez-Cataluña A, Tapiol J, Benavent C, Sarvisé C, Gómez F, Martínez B, et al. Antimicrobial susceptibility, virulence potential and sequence types associated with Arcobacter strains recovered from human faeces. J Med Microbiol. 2017;66(12):1736-43.

56. Van den Abeele AM, Vogelaers D, Vanlaere E, Houf K. Antimicrobial susceptibility testing of Arcobacter butzleri and Arcobacter cryaerophilus strains isolated from Belgian patients. J Antimicrob Chemother. 2016;71(5):1241-4.

57. Fanelli F, Chieffi D, Di Pinto A, Mottola A, Baruzzi F, Fusco V. Phenotype and genomic background of Arcobacter butzleri strains and taxogenomic assessment of the species. Food Microbiol. 2020;89:103416.

58. Müller E, Abdel-Glil MY, Hotzel H, Hänel I, Tomaso H. Aliarcobacter butzleri from water poultry: insights into antimicrobial resistance, virulence and heavy metal resistance. Genes. 2020;11(9):1104.

59. Rahimi E. Prevalence and antimicrobial resistance of Arcobacter species isolated from poultry meat in Iran. Br Poult Sci. 2014;55(2):174-80.

60. Wei B, Kang M. Molecular basis of macrolide resistance in Campylobacter strains isolated from poultry in South Korea. BioMed Res Int. 2018;2018:1-9.

61. Elmali M, Can HY. Occurence and antimicrobial resistance of Arcobacter species in food and slaughterhouse samples. Food Sci Technol. 2017;37(2):280-5

62. Fanelli F, Di Pinto A, Mottola A, Mule G, Chieffi D, Baruzzi F, et al. Genomic characterization of Arcobacter butzleri isolated from shellfish: Novel insight into antibiotic resistance and virulence determinants. Front Microbiol. 2019;10:670.

63. Zhao S, Tyson GH, Chen Y, Li C, Mukherjee S, Young S, et al. Wholegenome sequencing analysis accurately predicts antimicrobial resistance phenotypes in Campylobacter spp. Appl Environ Microbiol. 2016;82(2):459-66.

64. Vandewalle-Capo M, Massip C, Descours G, Charavit J, Chastang J, Billy PA et al. Minimum inhibitory concentration (MIC) distribution among wildtype strains of Legionella pneumophila identifies a subpopulation with reduced susceptibility to macrolides owing to efflux pump genes. Int J Antimicrob Agents. 2017;50(5):684-9.

65. Sciortino S, Arculeo P, Alio V, Cardamone C, Nicastro L, Arculeo M, et al. Occurrence and antimicrobial resistance of Arcobacter spp. recovered from aquatic environments. Antibiotics. 2021;10(3):288.

66. Riesenberg A, Frömke C, Stingl K, Feßler AT, Gölz G, Glocker EO, et al. Antimicrobial susceptibility testing of Arcobacter butzleri: development and application of a new protocol for broth microdilution. J Antimicrob Chemother. 2017;72(10):2769-74.

67. Girbau C, Guerra C, Martínez-Malaxetxebarria I, Alonso R, FernándezAstorga A. Prevalence of ten putative virulence genes in the emerging foodborne pathogen Arcobacter isolated from food products. Food Microbiol. 2015;52:146-9.
68. Karadas G, Sharbati S, Hänel I, Messelhäußer U, Glocker E, Alter T, et al. Presence of virulence genes, adhesion and invasion of Arcobacter butzleri. J Appl Microbiol. 2013;115(2):583-90.

69. Piva S, Gariano GR, Bonilauri P, Giacometti F, Decastelli L, Florio D, et al. Occurrence of putative virulence genes on Arcobacter butzleri isolated from three different environmental sites throughout the dairy chain. J Appl Microbiol. 2017;122(4):1071-7.

70. Douidah L, de Zutter L, Bare J, De Vos P, Vandamme P, Vandenberg O, et al. Occurrence of putative virulence genes in Arcobacter species isolated from humans and animals. J Clin Microbiol. 2012;50(3):735-41.

71. Šilha D, Vacková B, Šilhová L. Occurrence of virulence-associated genes in Arcobacter butzleri and Arcobacter cryaerophilus isolates from foodstuff, water, and clinical samples within the Czech Republic. Folia Microbiol (Praha). 2019;64(1):25-31.

72. Lehmann D, Alter T, Lehmann L, Uherkova S, Seidler T, Gölz G. Prevalence, virulence gene distribution and genetic diversity of Arcobacter in food samples in Germany. Berl Munch Tierarztl Wochenschr. 2015;128(3-4):163-8.

73. Sekhar MS, Tumati SR, Chinnam BK, Kothapalli VS, Sharif NM. Virulence gene profiles of Arcobacter species isolated from animals, foods of animal origin, and humans in Andhra Pradesh, India. Vet World. 2017;10(6):716-20.

74. van Driessche E, Houf K, Hoof J, Zutter L, Vandamme P. Isolation of Arcobacter species from animal feces. FEMS Microbiol Lett. 2003;229(2):243-8.

75. Atabay HI, Aydin F, Houf K, Sahin M, Vandamme P. The prevalence of Arcobacter spp. on chicken carcasses sold in retail markets in Turkey, and identification of the isolates using SDS-PAGE. Int J Food Microbiol. 2003;81(1):21-8.

76. Houf K, Tutenel A, Zutter L, Hoof J, Vandamme P. Development of a multiplex PCR assay for the simultaneous detection and identification of Arcobacter butzleri, Arcobacter cryaerophilus and Arcobacter skirrowii. FEMS Microbiol Lett. 2000;193(1):89-94.

77. Korczak BM, Stieber R, Emler S, Burnens AP, Frey J, Kuhnert P. Genetic relatedness within the genus Campylobacter inferred from rpoB sequences. Int J Syst Evol Microbiol. 2006;56(5):937-45.

78. Whiteduck-Léveillée J, Cloutier M, Topp E, Lapen DR, Talbot G, Villemur $R$, et al. Development and evaluation of multiplex PCR assays for rapid detection of virulence-associated genes in Arcobacter species. J Microbiol Methods. 2016;121:59-65.

\section{Publisher's Note}

Springer Nature remains neutral with regard to jurisdictional claims in published maps and institutional affiliations.

Ready to submit your research? Choose BMC and benefit from

- fast, convenient online submission

- thorough peer review by experienced researchers in your field

- rapid publication on acceptance

- support for research data, including large and complex data types

- gold Open Access which fosters wider collaboration and increased citations

- maximum visibility for your research: over 100M website views per year

At BMC, research is always in progress.

Learn more biomedcentral.com/submissions 